\title{
KOMUNITAS BIOTA PENEMPEL PADA TERUMBU BUATAN DI PERAIRAN PULAU GANTENG DAN PULAU RAKIT, TELUK SALEH, NUSA TENGGARA BARAT
}

\author{
Amran Ronny Syam ${ }^{1)}$, Sri Turni Hartati'2), dan Krismono') \\ 1) Peneliti pada Loka Riset Pemacuan Stok Ikan, Jatiluhur-Purwakarta \\ 2) Peneliti pada Balai Riset Perikanan Laut, Muara Baru-Jakarta
}

Teregristrasi I tanggal: 15 Januari 2007; Diterima setelah perbaikan tanggal: 11 Juni 2007; Disetujui terbit tanggal: 11 Juli 2007

\begin{abstract}
ABSTRAK
Rehabilitasi perairan melalui peletakan terumbu buatan di perairan Teluk Saleh telah dilakukan sejak bulan Juli 2005 yang merupakan awal dari perbaikan perairan karang di kawasan itu. Tujuan penelitian ini adalah mengidentifikasi biota penempel pada terumbu buatan dan mengamati perubahan yang terjadi dari waktu ke waktu. Metode yang digunakan adalah pengamatan sensus visual dengan penyelaman SCUBA di sekitar terumbu buatan. Hasil analisis menunjukkan ada peningkatan jumlah jenis biota penempel selama kurun waktu 10 bulan peletakkan modul terumbu buatan. Komunitas biota penempel pada umumnya didominasi oleh kelompok alga dan other fauna. Selama kurun waktu tersebut belum menunjukkan ada perubahan (suksesi) ke arah pembentukkan hard coral.
\end{abstract}

KATAKUNCl: $\quad$ komunitas biota penempel, karang buatan, Teluk Saleh, Nusa Tenggara Barat

ABSTRACT: Bioufalling community in the artificial reef of Ganteng Island and Rakit Island on the Saleh Bay Waters, Nusa Tenggara Barat. By: Amran Ronny Syam, Sri Turni Hartati, and Krismono

Rehabilitation of water has been done through installation of artificial reef in Saleh Bay since July 2005. The activity should represent early stade up of coral reef waters. The objective of this research is to identify bioufalling communities on the artificial reef and perceive change of then from time to time. This work used a method enhancment of visual census with diving of SCUBA around artificial reef. Results show the improvements species and abundance of bioufalling during periode of 10 month when artificial reef module was settled. The community of bioufalling was generally predominated by group of algae and other fauna. Succession of the communities during the periode of study was not yet to forming hard coral formation.

KEYWORDS: bioufalling communities, artificial reef, Saleh Bay, Nusa Tenggara Barat

\section{PENDAHULUAN}

Terumbu karang alami di perairan Indonesia kian hari semakin mendapat tekanan akibat berbagai aktivitas manusia. Kerusakkan terumbu karang antara lain disebabkan oleh penggunaan bahan peledak, bahan kimia beracun dalam penangkapan ikan, perusakkan dan pengambilan karang batu sebagai bahan bangunan serta ada pencemaran dan bencana alam. Hasil penelitian kondisi terumbu karang alami di sekitar pantai barat Teluk Saleh, Kabupaten Sumbawa Besar menunjukkan kondisi yang rusak (Hartati et al., 2004; Hartati et al., 2005; Soekarno et al., 1983). Hal yang sama dengan kondisi terumbu karang Indonesia yang tercatat $40 \%$ dalam keadaan rusak, $24 \%$ rusak sedang, dan kondisi yang sangat baik hanya 4\% (Mawardi, 2003). Pemulihan kembali kondisi terumbu karang yang rusak itu membutuhkan waktu yang lama yaitu sekitar 20 sampai dengan 40 tahun (Endean, 1976). Dalam upaya menanggulangi masalah kerusakkan terumbu karang, salah satu cara yang dapat ditempuh adalah rehabilitasi habitat melalui pengembangan teknologi terumbu buatan (Loka Riset Pemacuan Stok Ikan, 2004-2006).

Sebagai indikator untuk mengetahui perubahanperubahan kondisi terumbu buatan, maka pengamatan komunitas biota penempel merupakan salah satu langkah pemantauan dari proses penempelan biota karang pada substrat terumbu buatan. Proses ini akan berlanjut sampai dengan akhirnya membentuk komunitas hard coral sehingga terumbu buatan menjadi ekosistem terumbu karang yang mendekati sifat alami. Penelitian komunitas biota penempel telah dilakukan di berbagai wilayah antara lain di perairan Jemeluk, Bali, dan perairan Selat Sunda (Yusniasita, 1994; Edrus et al., 1996; Edrus, 2002; Darsono \& Hutomo, 1983).

Tujuan penelitian ini adalah untuk mengidentifikasi jenis dan jumlah bentuk kehidupan karang (benthic life form) sebagai indikator ada perubahan-perubahan

Kosrespondensi penulis:

Jl. Cilalawi, Purwakarta, Purwakarta 41152, E-mail: irpsi@yahoo.com dan irpsi@telkom.net.id 
komunitas biota penempel seiring dengan lama waktu peletakan modul terumbu buatan. Perubahan-perubahan ini yang nanti akan menunjukkan telah berfungsi tidak terumbu buatan sebagai shelter berbagai biota laut lain.

\section{BAHAN DAN METODE}

Penelitian dilakukan pada bulan Oktober, Desember 2005, dan April 2006 di perairan Pulau Ganteng dan Pulau
Rakit (Tanjung Bila), kawasan Teluk Saleh-Nusa Tenggara Barat (Gambar 1). Empat unit terumbu buatan telah diletakkan di perairan tersebut pada bulan Juli 2005 dalam konfigurasi piramida masing-masing 2 unit di perairan Pulau Ganteng dan 2 unit lain di perairan Pulau Rakit. Unit terumbu buatan di Pulau Ganteng terdiri atas 1 unit di bagian selatan (stasiun 1) dan 1 unit di bagian utara (stasiun 2), sedangkan di Pulau Rakit terdiri atas 1 unit di bagian timur (stasiun 3) dan 1 unit di bagian barat (stasiun 4).

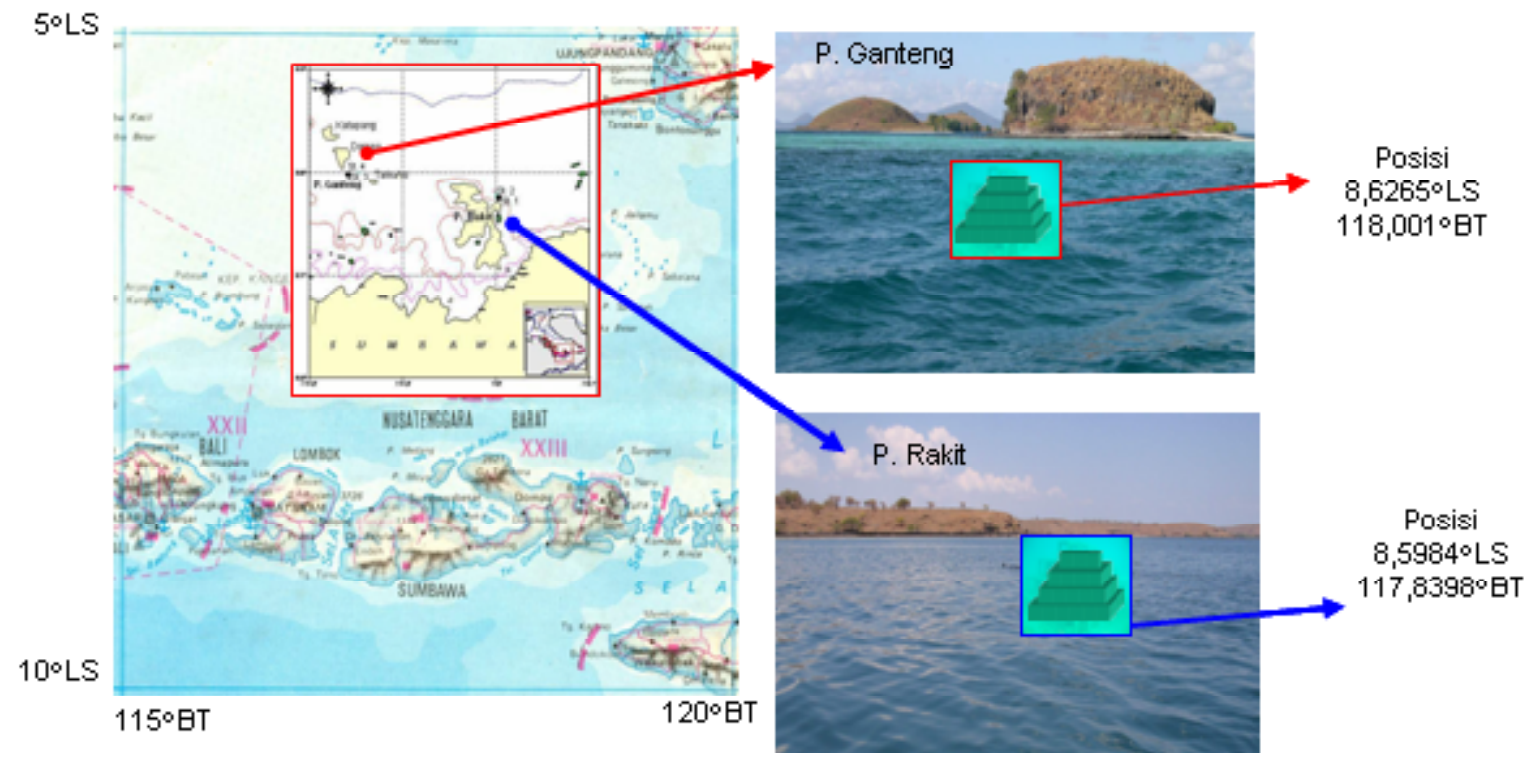

Gambar 1. Letak posisi unit terumbu buatan (artificial reef) di perairan Pulau Ganteng dan Pulau Rakit, kawasan perairan Teluk Saleh-Kabupaten Sumbawa Besar-Nusa Tenggara Barat.

Figure 1. Position of artificial reef builders on the water area of Ganteng Island and Rakit Island in Saleh Bay water, Regency of Sumbawa Besar, Nusa Tenggara Barat.

Modul terumbu buatan terbuat dari beton, berbentuk kubus berongga, berukuran $60 \times 60 \times 60 \mathrm{~cm}$ (panjangxlebarxtinggi). Satu unit terumbu buatan tersusun dari 80 modul yang membentuk konfigurasi piramida (Gambar 2). Pengamatan biota penempel pada terumbu buatan dilakukan dengan penyelaman SCUBA dengan mengidentifikasi dan mencacah benthic life form secara sensus visual. Benthic life form tersebut terdiri atas hard coral dengan 12 komponen, dead scleractinia 2 komponen, algae 5 komponen, other fauna 4 komponen, dan abiotic 5 komponen (English et al., 1994).

Format komponen benthic life form disajikan pada Tabel 1. Identifikasi jenis biota penempel dilakukan berdasarkan pada buku petunjuk Carpenter \& Niem (1998); Romimohtarto \& Juwana (2005). 


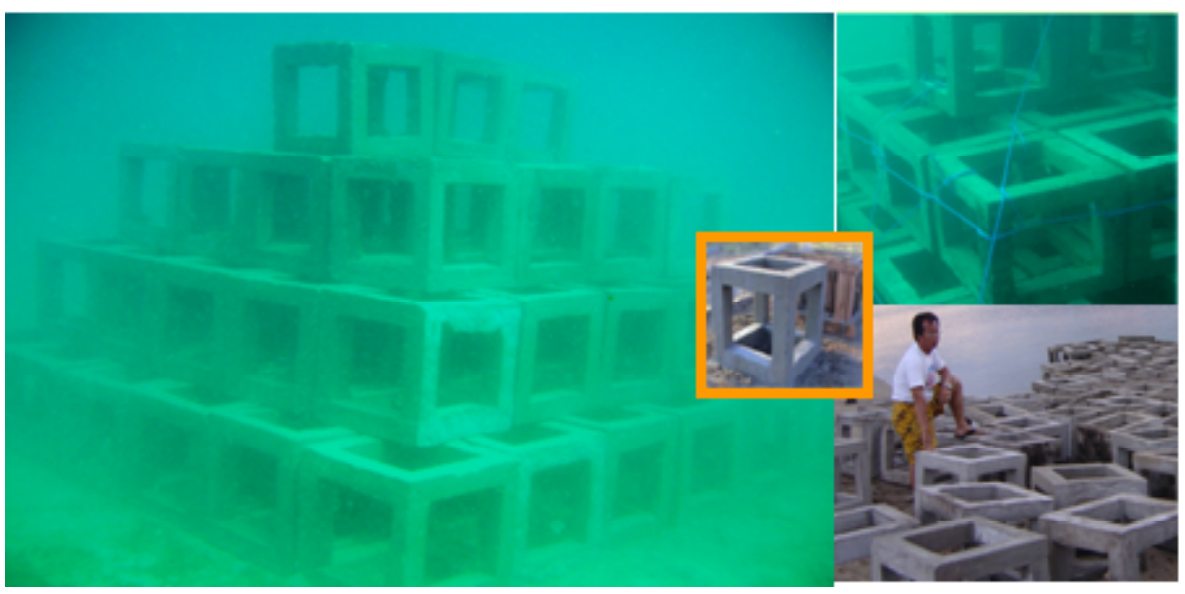

Gambar 2. Formasi modul terumbu buatan yang dipasang pada perairan Teluk Saleh.

Figure 2. Formation of module artificial reef where settled on the Saleh Bay waters.

Tabel 1. Format benthic life form sebagai indikator untuk penggolongan biota penempel (English et al., 1994)

Table 1. The format of benthic life form as indicator for classification of bioufalling communities (English et al., 1994)

\begin{tabular}{cc}
\hline Benthic life form & Code \\
\hline Hard corals (acropora) & ACB \\
Branching & ACT \\
Tabulate & ACE \\
Encrusting & ACS \\
Submassiv & \\
\hline Hard coral (non-acropora) & \\
\hline Branching & CB \\
Massive & CM \\
Encrusting & CE \\
Submassive & CS \\
Foliose & CF \\
Mushroom & CMR \\
Millepora & CME \\
Heliopora & CHL \\
\hline Dead scleractinia & \\
\hline Dead Coral & DC \\
(With Algal Covering) & DCA
\end{tabular}

\section{HASIL DAN BAHASAN}

\section{Hasil}

Hasil pengamatan biota penempel pada 4 unit terumbu buatan yang dipasang pada perairan Pulau Ganteng dan Pulau Rakit selama 3 periode pengamatan mengalami

\begin{tabular}{lc}
\hline \multicolumn{1}{c}{ Benthic life form } & Code \\
\hline Algae & MA \\
\hline Macro & TA \\
Turf & CA \\
Coralline & HA \\
Halimedae & AA \\
Algal Assemblage & \\
\hline Other Fauna & SC \\
\hline Soft Corals & SP \\
Sponge & ZO \\
Zoanthids & OT \\
Other & \\
& \\
& \\
& \\
\hline Abiotic & \\
\hline Sand & \\
Rubble & S \\
Silt & R \\
Water & SI \\
Rock & WA \\
\hline
\end{tabular}

peningkatan jumlah jenis biota penempel. Gambar 3 menyajikan perkembangan biota penempel menurut waktu, dan Lampiran 1 menyajikan komposisi jenis secara rinci. Pada periode bulan Oktober 2005 yang merupakan masa 4 bulan peletakan terumbu buatan didominasi oleh kelompok alga dan teritip. Baik di Pulau Ganteng maupun di Pulau. 


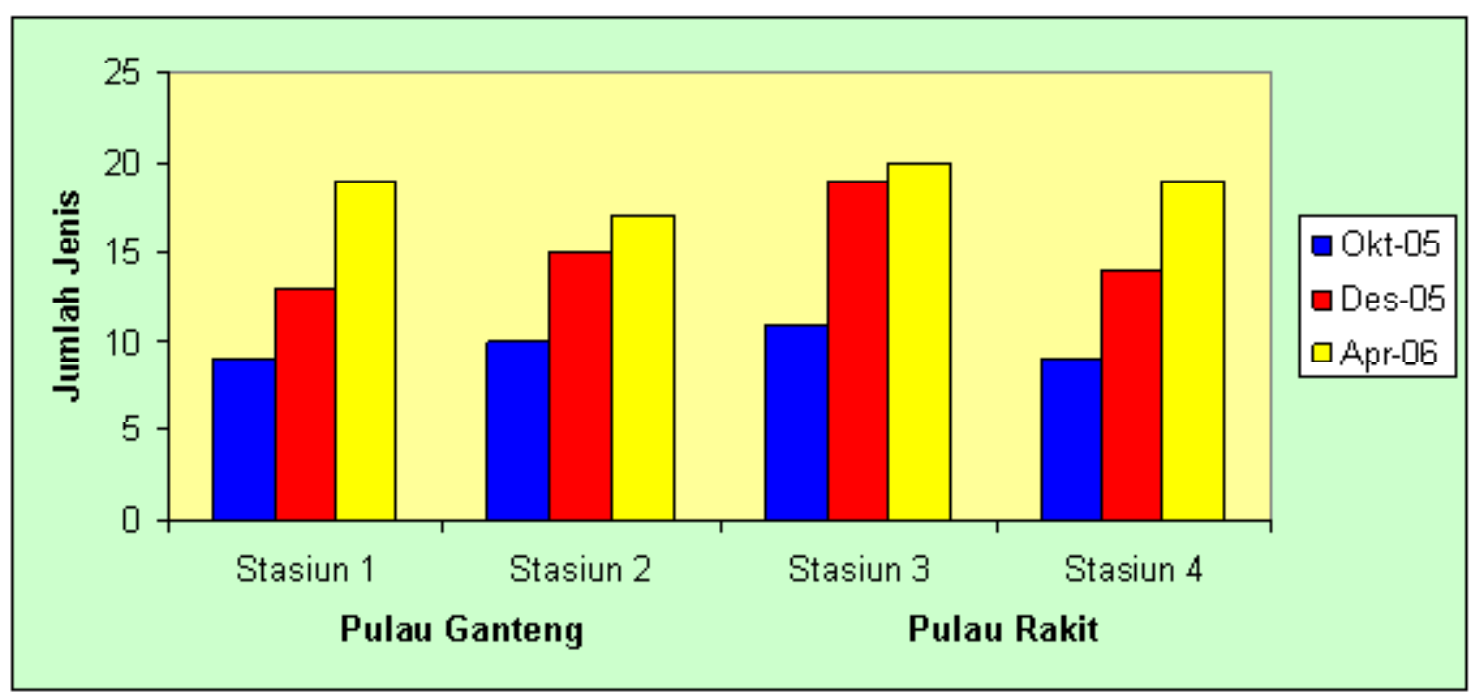

Gambar 3. Jumlah jenis biota penempel pada terumbu buatan di perairan Pulau Ganteng dan Pulau Rakit, Teluk Saleh, Nusa Tenggara Barat, periode bulan Oktober, Desember 2005, dan April 2006.

Figure 3. Species and abundance of bioufalling communities on the water of Ganteng Island and Rakit Island, Bay of Saleh, Nusa Tenggara Barat, in period of October, December 2005, and April 2006.

Rakit terlihat lebih dari sepertiga bagian kubus terumbu buatan ditumbuhi biota penempel yang didominasi oleh kelompok alga (Enteromorpha) dan teritip (Saccostrea cucculata). Pada periode bulan Desember 2005 (bulan ke-6 sejak peletakkan terumbu buatan) kelompok alga tetap mendominasi permukaan terumbu buatan terutama jenis Enteromorpha. Dalam periode waktu 6 bulan ini jumlah jenis mulai bertambah dari semula 16 jenis menjadi 22 jenis biota penempel. Beberapa jenis biota penempel mengalami jumlah individu yang berfluktuasi, beberapa jenis biota penempel menghilang dan diganti dengan menempel jenis baru. Pada periode bulan April 2006 (10 bulan masa peletakkan) terjadi peningkatan komponen biota penempel sampai dengan mencapai 29 jenis. Terlihat pada masa 10 bulan ini, kelompok alga tetap mendominasi permukaan terumbu buatan sekitar $57,8 \%$ dari jumlah total 3.935 individu, teritip sekitar $13,5 \%$ dan tunicata $12,2 \%$. Secara umum, didapatkan 3 kelompok biota yang menonjol kehadiran yaitu alga (Enteromorpha dan Padina), kelompok teritip (Saccostrea cuccullata), dan kelompok bivalvia (Pinctada margaritifera). Selain itu, pada periode ini didapatkan beberapa jenis biota pendatang baru yang muncul terutama pada kelompok other fauna. Beberapa jenis biota penempel pada terumbu buatan di perairan Pulau Ganteng dan Pulau Rakit secara kualitatif disajikan pada Lampiran 1, dan secara kuantitatif jumlah individu per jenis biota penempel pada bulan April 2006 disajikan pada Lampiran 2, serta gambar beberapa jenis biota penempel disajikan pada Lampiran 3.

\section{Bahasan}

Biota penempel adalah berbagai jenis biota baik hewan maupun tumbuhan serta bakteri yang melekat pada suatu substrat keras. Setiap benda yang terendam dalam air laut pada umumnya dapat ditempeli oleh biota penempel (bioufalling communities). Biota penempel tersebut sebagian besar tergolong dalam Avertebrata dan biota lain yang terlihat pada terumbu buatan seperti kelompok bentos (biota yang menetap di dasar), kelompok merayap, sebagian kelompok biota yang bersifat komensalisme, simbiose, dan parasit atau predator (Sukarno et al., 1993).

Suksesi biota penempel pada benda yang terendam air laut diawali oleh penempelan dan membentuk suatu lapisan tipis (primary film), kemudian seiring dengan waktu membentuk kolonisasi komunitas yang tumbuh di kalangan diatom bentik, spora alga, dan larva berbagai jenis hewan lain. Zo Bell dalam Yusniasita (1983) mengatakan kelompok bryozoa, hydrozoa, cirripedia, tunikata, alga, dan biota lain berkembang kemudian setelah terbentuk lapisan film oleh bakteri. Biota lain yang sering terlihat adalah cacing, kepiting, keong, dan kekerangan. Darsono \& Hutomo (1983) mengamati perkembangan biota penempel dalam setahun yang diawali oleh 4 jenis pada hari ke-60 dan bertambah menjadi 11 jenis sampai dengan hari ke-270. (BaileyBrock, 1989 in Yusniasita N. E., 1994) mendapatkan hasil pengamatan jumlah jenis biota penempel pada terumbu 
buatan di perairan Hawai yang diawali oleh 7 jenis pada hari ke-16 dan 28 jenis pada hari ke-385. Dalam penelitian ini perkembangan biota penempel menunjukkan peningkatan dari 16 jenis pada pengamatan pertama (hari ke-120) menjadi 29 jenis pada hari ke-300. Meskipun ada peningkatan jumlah jenis namun perkembangan biota penempel pada terumbu buatan di Teluk Saleh belum menunjukkan ada suksesi pembentukkan koloni karang keras (hard coral). Perkembangan biota penempel tersebut dalam fase kolonisasi biota-biota perintis. Terjadi suksesi menuju ke pembentukan hard coral membutuhkan puluhan tahun seperti yang telah dilakukan di perairan Jemeluk Bali (Edrus, 2002).

Jika dibandingkan perkembangan jumlah jenis biota penempel pada terumbu buatan di perairan Teluk Saleh (Pulau Ganteng dan Pulau Rakit) dengan beberapa hasil penelitian yang lain menunjukkan hasil yang relatif tidak jauh berbeda (Gambar 4 dan 5), kesemua mengalami peningkatan jumlah jenis seiring dengan bertambah waktu kecuali pada hasil penelitian di Teluk Jakarta terdapat penurunan di akhir tahun.

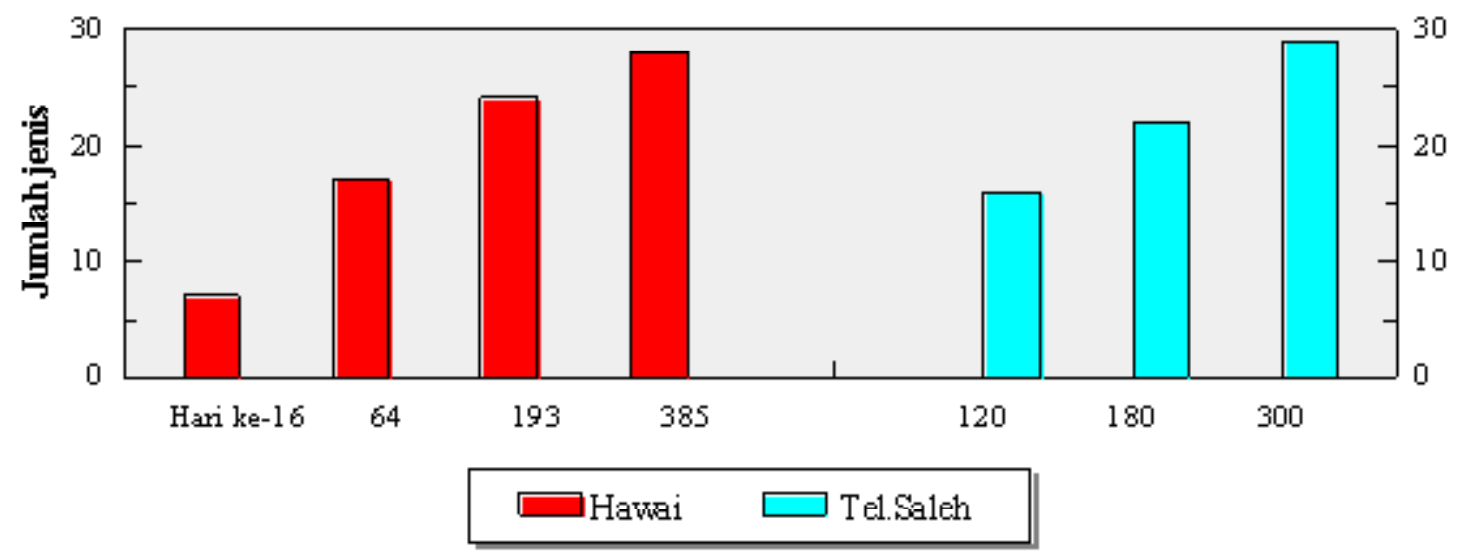

Gambar 4. Jumlah jenis biota penempel pada terumbu buatan di berbagai tempat antara lain di perairan Teluk Saleh, Nusa Tenggara Barat (hasil penelitian ini) dan di Hawai.

Sumber: Bailey-Brock, 1989

Figure 4. Species and abundance of bioufalling communities on the artificial reef in various places for example in water area of Bay of Saleh, Nusa Tenggara Barat (result of this research), and Hawai. Sources: Bailey-Brock, 1989

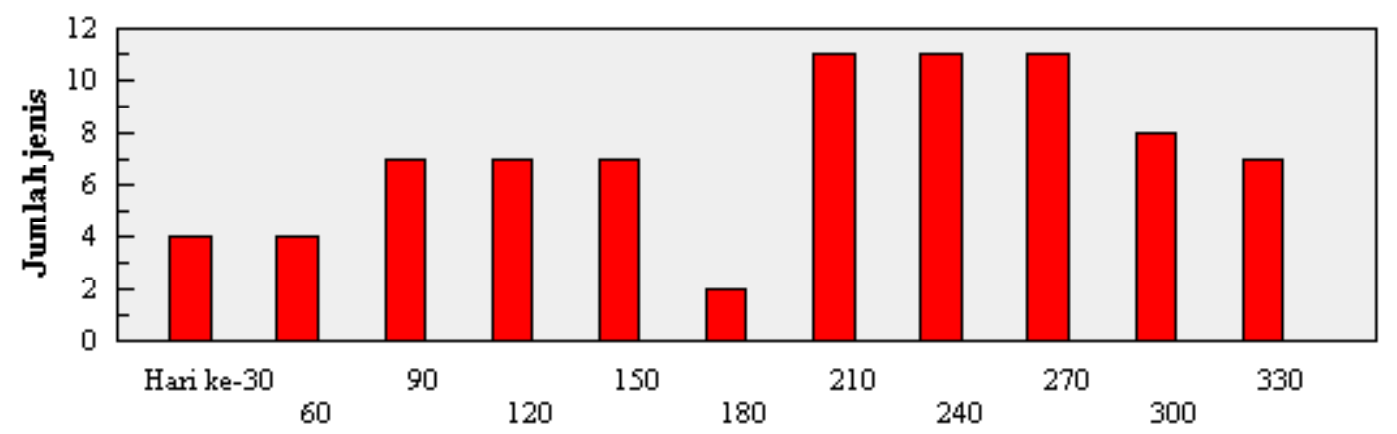

Gambar $5 . \quad$ Jumlah jenis biota penempel pada terumbu buatan di Teluk Jakarta.

Figure 5. Species and abundance of bioufalling communities on the artificial reef in Jakarta Bay. Sources: Darsono \& Hutomo, 1983 


\section{KESIMPULAN}

1. Biota penempel yang hadir pada terumbu buatan di perairan Pulau Rakit dan Pulau Ganteng pada umumnya dalam kelompok Alga dan Other fauna.

2. Perkembangan biota penempel terumbu buatan dalam tahap kolonisasi dan belum menunjukkan ada perubahan (suksesi) menuju ke pembentukkan koloni hard coral.

3. Jumlah jenis biota penempel sampai dengan pada hari ke-300 mencapai 29 jenis.

\section{PERSANTUNAN}

Kegiatan dari hasil riset perkembangan stok sumber daya perairan karang pasca rehabilitasi habitat di Teluk Saleh, Nusa Tenggara Barat dan Jemuluk, Bali, T.A. 2006, di Anggaran Pendapatan Belanja Negara.

\section{DAFTAR PUSTAKA}

Carpenter, K. E. \& V. H. Niem. 1998. The living marine resources of the western Central Pasific. Vol.1 seaweeds, coral, bivalves, and gastropods. Food and Agriculture Organization of the United Nations. Rome. 686: 25-648.

Darsono, P. \& M. Hutomo. 1983. Komunitas biota penempel di perairan Suralaya, Selat Sunda. Oseanologi di Indonesia. Lembaga Osenologi Nasional. Lembaga Ilmu Pengetahuan Indonesia. Jakarta. 16: 29-41.

Edrus I. N. 2002. Assessment of community participation in the coastal resource rehabilitation project in Bali, Indonesia. Thesis. University of the Phillippines Los Banos.

Edrus, I. N., A. R. Syam, \& Suprapto. 1996. Penelitian komunitas ikan pada terumbu buatan di perairan Dusun Jemeluk, Kabupaten Amlapura, Bali. Jurnal Penelitian Perikanan Indonesia. II (1): 1-14.

Endean R. 1976. Destruction and recovery of coral reef communities in biology and geology of coral reef.
Jones, O. A. \& R. Endean (Eds.). Academic Press. New York. 3:215.

English, S., C. Wilkinson, \& V. Baker. 1994. Survey manual for tropical marine resources. Australian International Development Assistance Bureau. Australian Institute of Marine Science. Townsville. 1251.

Hartati, S. T., A. Thamin, S. E. Purnamaningtyas, Mujiyanto, Wasilun, I. Suprihanto, \& S. M. Syarif. 2005. Rehabilitasi habitat dan pemacuan stok sumber daya perairan karang di Teluk Saleh, Nusa Tenggara Barat. Loka Riset Pemacuan Stok Ikan. Jatiluhur. Pusat Riset Perikanan Tangkap. Badan Riset Kelautan dan Perikanan.

Hartati, S. T., Awwaluddin, \& N. Siti. 2004. Identifikasi habitat dan pemacuan stok sumber daya perairan karang di Teluk Saleh, Nusa Tenggara Barat. Laporan Akhir Kegiatan Penelitian. Pusat Riset Perikanan Tangkap.

Loka Riset Pemacuan Stok Ikan. 2004-2006. Laporan Tahunan Loka Riset Pemacuan Stok Ikan. Loka Riset Pemacuan Stok Ikan. Jatiluhur.

Mawardi, W. 2003. Ekosistem terumbu karang: Peranan, kondisi, dan konservasinya. Makalah Falsafah Sains (PPs.702) Program Pascasarjana. Institut Pertanian Bogor. Bogor.

Romimohtarto, K. \& S. Juwana. 2005. Biologi laut; IImu pengetahuan tentang biologi laut. Cetakan ke-2. Djambatan. Jakarta.

Sukarno, Hutomo M., Moosa M. K., \& Darsono P. 1983. Terumbu karang di Indonesia. Lembaga Oseanologi Nasional. Lembaga IImu Pengetahuan Indonesia. Jakarta. $18 \mathrm{~h}$.

Sukarno, Hutomo M., Moosa M. K., \& Darsono P. 1993. Terumbu karang di Indonesia: Sumber daya, permasalahan, dan pengelolaannya. Lembaga Oseanologi Nasional. Lembaga IImu Pengetahuan Indonesia. Jakarta.

Yusniasita, N. E. 1994. Terumbu buatan sebagai habitat biota penempel. Fakultas Biologi. Universitas Nasional. Jakarta. 


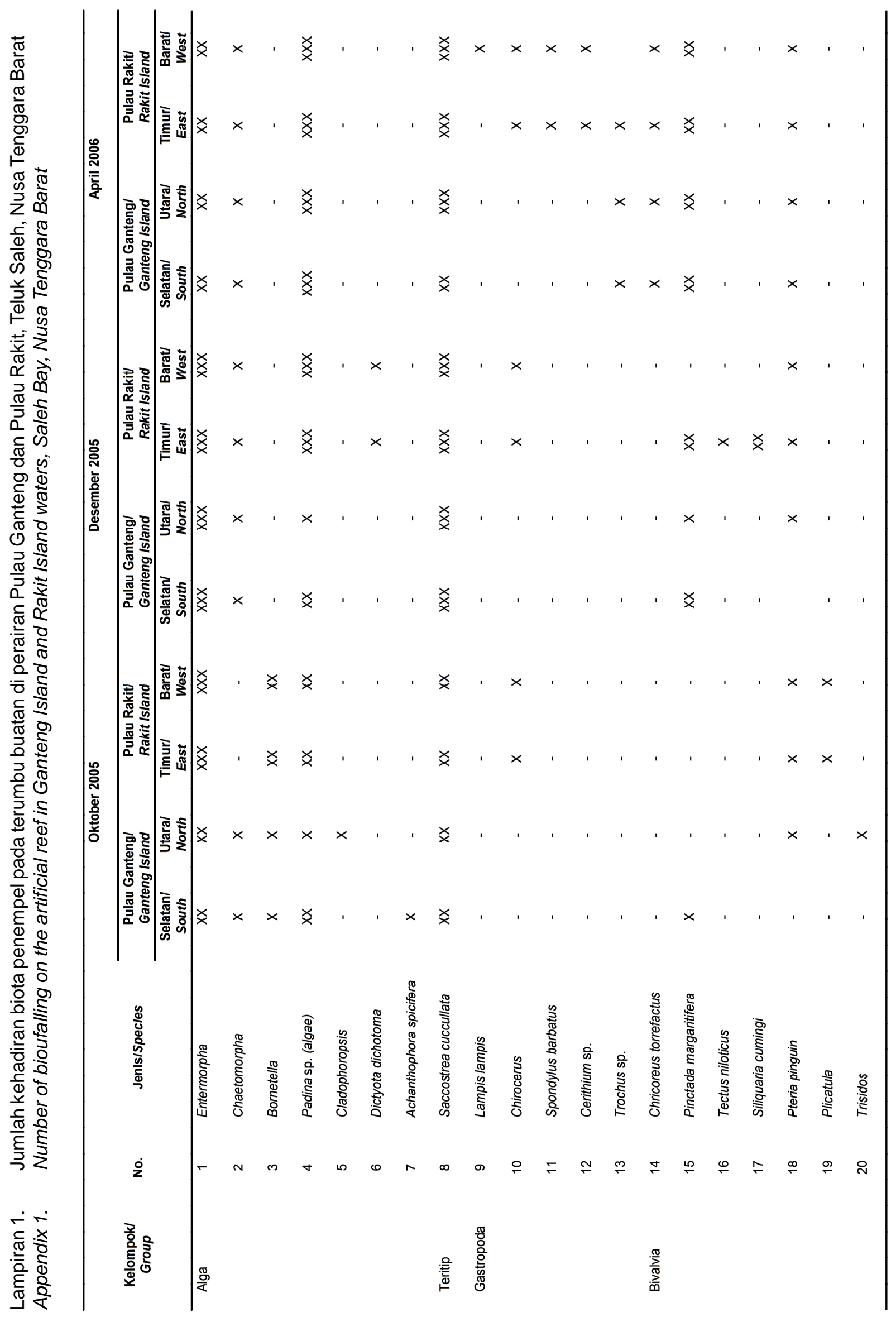




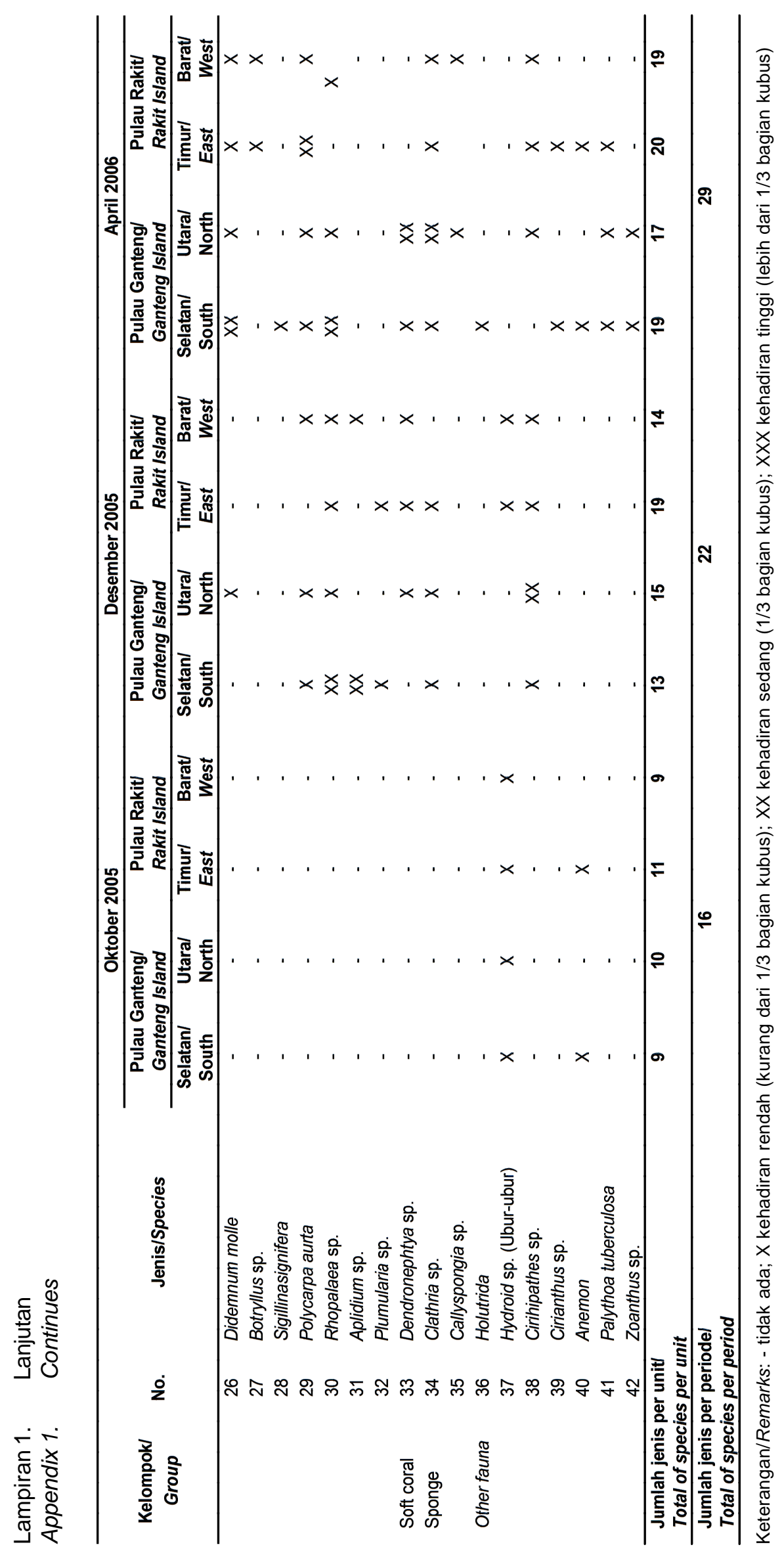


Lampiran 2. Jumlah Individu dan spesies biota penempel pada terumbu buatan di perairan Pulau Ganteng dan Pulau Rakit, Teluk Saleh, Nusa Tenggara Barat, bulan April 2006

Appendix 2. Individual number and bioufalling species on artificial reef in Ganteng Island and Rakit Island waters, Saleh Bay, Nusa Tenggara Barat, April 2006

\begin{tabular}{|c|c|c|c|c|c|c|}
\hline \multirow{2}{*}{ Kelompok/Group } & \multirow{2}{*}{ No. } & \multirow{2}{*}{ Jenis/Species } & \multicolumn{2}{|c|}{$\begin{array}{l}\text { Pulau Ganteng/ } \\
\text { Ganteng Island }\end{array}$} & \multicolumn{2}{|c|}{$\begin{array}{l}\text { Pulau Rakit/ } \\
\text { Rakit Island }\end{array}$} \\
\hline & & & $\begin{array}{c}\text { Selatan/ } \\
\text { South }\end{array}$ & $\begin{array}{l}\text { Utara/ } \\
\text { North }\end{array}$ & $\begin{array}{c}\text { Timur/ } \\
\text { East }\end{array}$ & $\begin{array}{r}\text { Barat// } \\
\text { West }\end{array}$ \\
\hline \multirow[t]{7}{*}{ Alga } & 1 & Entermorpha & 340 & 320 & 195 & 274 \\
\hline & 2 & Chaetomorpha & 10 & 12 & 9 & 13 \\
\hline & 3 & Bornetella & - & - & - & - \\
\hline & 4 & Padina sp & 334 & 299 & 274 & 195 \\
\hline & 5 & Cladophoropsis & - & - & - & - \\
\hline & 6 & Dictyota dichotoma & - & - & - & - \\
\hline & 7 & Achanthophora spicifera & - & - & - & - \\
\hline Teritip & 8 & Saccostrea cuccullata & 60 & 156 & 105 & 210 \\
\hline \multirow[t]{5}{*}{ Gastropoda } & 9 & Lampis lampis & - & - & - & 1 \\
\hline & 10 & Chirocerus & - & - & 17 & 16 \\
\hline & 11 & Spondylus barbatus & - & - & 13 & 3 \\
\hline & 12 & Cerithium $s p$ & & & 4 & 10 \\
\hline & 13 & Trochus sp & 2 & 2 & 1 & - \\
\hline \multirow[t]{7}{*}{ Bivalvia } & 14 & $\begin{array}{l}\text { Chricoreus torrefactus (kerang } \\
\text { merah) }\end{array}$ & 15 & 12 & 15 & 12 \\
\hline & 15 & Pinctada margaritifera & 31 & 35 & 35 & 38 \\
\hline & 16 & Tectus niloticus & - & - & - & - \\
\hline & 17 & Siliquaria cumingi & - & - & - & - \\
\hline & 18 & Pteria pinguin & 5 & 22 & 2 & 1 \\
\hline & 19 & Plicatula & - & - & - & - \\
\hline & 20 & Trisidos & - & - & - & - \\
\hline Echinoidea & 21 & Diadema savignyi & 5 & 2 & 22 & 75 \\
\hline \multirow[t]{11}{*}{ Tunicat } & 22 & Ascidian & - & - & - & - \\
\hline & 23 & Eusynstyela sp & 185 & 16 & 87 & 18 \\
\hline & 24 & Protula sp & - & - & - & - \\
\hline & 25 & Leptoclinides reticulatus & - & - & 4 & 7 \\
\hline & 26 & Didemnum molle & 30 & 6 & 7 & 2 \\
\hline & 27 & Botryllus sp & - & - & 13 & 5 \\
\hline & 28 & Sigillinasignifera & 6 & - & - & - \\
\hline & 29 & Polycarpa aurta & 10 & 8 & 16 & 13 \\
\hline & 30 & Rhopalaea $s p$ & 31 & 12 & & 6 \\
\hline & 31 & Aplidium $s p$ & - & - & - & - \\
\hline & 32 & Plumularia $s p$ & - & - & - & - \\
\hline Soft coral & 33 & Dendronephtya sp & 18 & 21 & - & - \\
\hline \multirow[t]{2}{*}{ Sponge } & 34 & Clathria sp & 25 & 61 & 15 & 21 \\
\hline & 35 & Callyspongia sp & - & 2 & - & 2 \\
\hline \multirow[t]{7}{*}{ Other Fauna } & 36 & Holutrida & 2 & & & \\
\hline & 37 & Hydroid sp (Ubur-ubur) & - & - & - & - \\
\hline & 38 & Cirihipathes $s p$ & & 5 & 13 & 4 \\
\hline & 39 & Cirianthus sp & 2 & & 1 & \\
\hline & 40 & Anemon & 2 & & 3 & \\
\hline & 41 & Palythoa tuberculosa & 4 & 8 & 8 & \\
\hline & 42 & Zoanthus sp & 20 & 14 & & \\
\hline \multicolumn{3}{|c|}{ Jumlah individu/Total of individu } & 1.137 & 1.013 & 859 & 926 \\
\hline \multicolumn{3}{|c|}{ Jumlah jenis/Total of species } & 21 & 19 & 22 & 21 \\
\hline
\end{tabular}


Lampiran 3. Beberapa jenis biota penempel pada terumbu buatan di perairan Pulau Ganteng dan Pulau Rakit, Teluk Saleh, Nusa Tenggara Barat

Appendix 3. Some of bioufally species on artificial reef is Ganteng Island and Rakit Island in Saleh Bay, Nusa Tenggara Barat

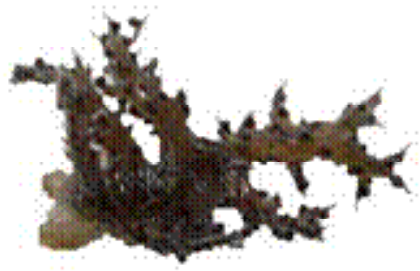

Soft coral (Dendronephyta sp.)

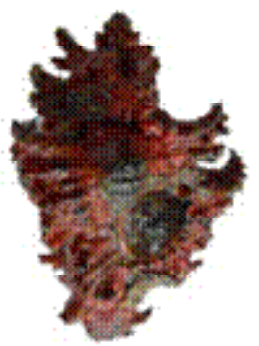

Chricoreus torrefactus

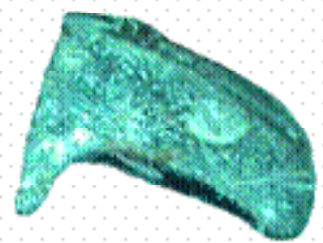

Pteria pinguin

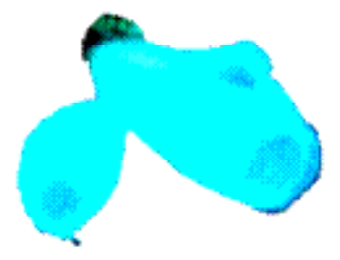

Rhopalaeasp.

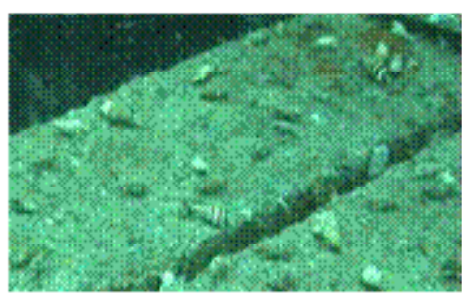

Cerithium sp.

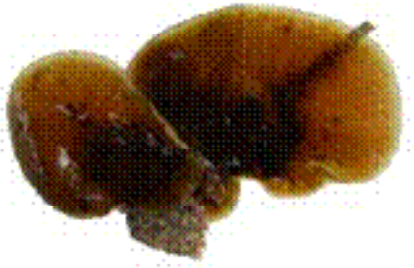

Padina sp.

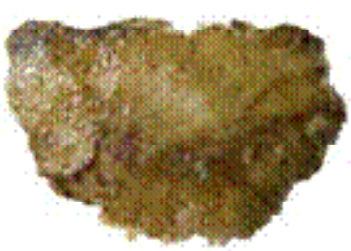

Saccostrea cuccullata

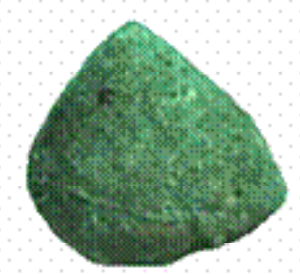

Trochus sp

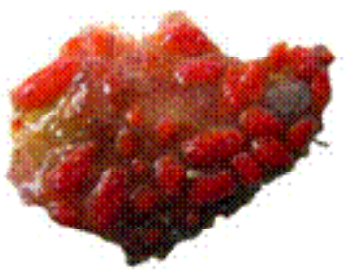

Eusynstyela sp.

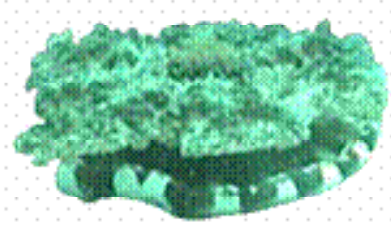

Ubur-ubur (Hydroidsp.)

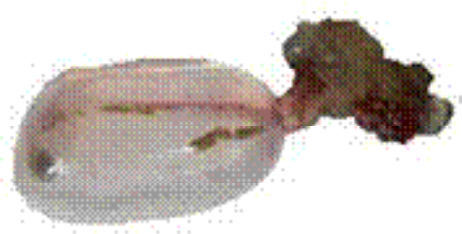

Rhopalaea crussa

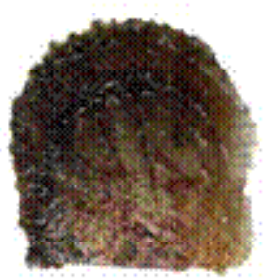

Pinctada margaritifera

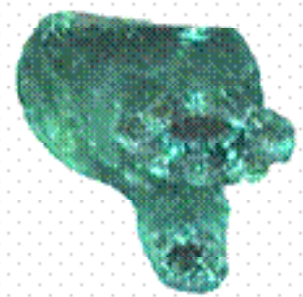

Polycarpa aurta

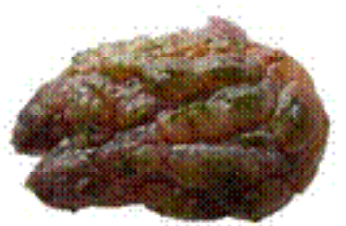

Polycarpa aurta

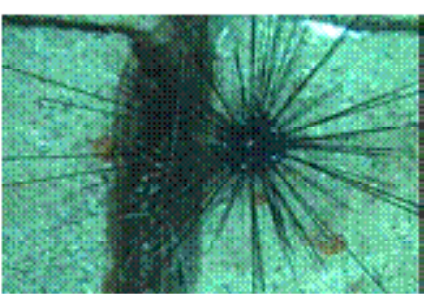

Diadema savignyi 